\title{
ICHTHYOLOGY AND ECONOMIC IMPORTANCE OF BALTIC HERRING IN POLISH FISH INDUSTRY
}

\author{
Department of Dairy Technology and Food Storage, West Pomeranian University of Technology, \\ Szczecin, Poland
}

\begin{abstract}
For Polish fishery herring is a common material acquired from Baltic Sea. Despite the homogeneity of this species, herring is divided for many different types due to the geographical location of each shoal. Differences in the anatomic features between the types of herring indicate many adaptation attributes to environment in which this species lives. As a result, geographical division influences on spawning season, amount of laid eggs, size of eggs and the spawning period. These attributes are related with environmental conditions of given season. Herring belongs to fat fish, what affects meat properties, processing methods and types of products that can be obtained. Spawning season decides about mass yield of herring production and sensory quality of products. Herring meat is good source of necessary unsaturated fatty acids, essential amino acids, minerals and vitamins. The composition of herring meat indicates that it is favourable element of daily diet. Moreover, the price of this species is low in comparison to other fish. Additional benefit of the processing is, that also herring by-products find technological applications what reduces loss in fish processing industry.
\end{abstract}

Key words: Baltic herring; ichthyology; fish industry; by-products; fish nutritional value.

\section{INTRODUCTION}

Herring (Clupea harengus) belongs to the bony fish. The herring family includes, among others: herring, sprat, sardine and sardinella. Herring occurs in the area from the North Atlantic to the English Channel and in the Baltic Sea. It creates many local breeds, varieties and ecological groups, e.g. Atlantic-Scandinavian Herring, Shelf Herring and Baltic Herring (Terofal and Militz 1996). Herring is a pelagic fish, living in large shoals and undertakes spawning and feeding migrations (Więcaszek 1999). It is extensively used and has great economic importance resulting from its participation in global fishing and multilateral usefulness (Von Dorrien et al. 2013; Hernandez-Padilla et al. 2017). In comparison with herring from the North Sea, Baltic herring are considered as raw material with lower technological suitability. This fish goes into trade in a fresh or frozen state, ungutted or in the form of fillets. Baltic herring as a smaller fish than Atlantic herring is prepared into fillets and also to carcasses form. In Poland it is processed primarily to variety of marinades, canned, salted as well as cold or hot smoked (Ankenman-Granata et al. 2012; Kulikowski 2017). The assortment of herring in Poland is small, however fresh and frozen herring is in some

Corresponding author: Mariusz Szymczak, Department of Dairy Technology and Food Storage, West Pomeranian University of Technology, Szczecin, Papieża Pawła VI 3, 71-450 Szczecin, Poland, e-mail: mariusz.szymczak@zut.edu.pl 
extension used in gastronomy as well as in households. Salting is the basic treatment of both fresh or frozen herring for the preparation of various dishes and various preserves (Konerzewski et al. 1968). Herring's meat has an intense fishy taste that is often not as attractive as in the case of other fish with white and salmon colour meat, like salmon, cod and pollock. For that reason, consumers choose it mainly due to its low price and high nutritional value (Od kilku lat rośnie konsumpcja ryb 2015; Tkaczewska et al. 2014).

Catches of Baltic herring (Clupea harengus membrans) contribute a large part of the catches made by Polish fishermen. In 2015, 39.7 thousand tonnes of herring were caught in the Baltic fisheries (which accounted for $21.2 \%$ of total catches), in 2016, 44.1 thousand tonnes (GUS 2016), and in 2017, 51.3 thousand tonnes of herring (Karnicki 2017) - Fig. 3. The amount of herring catches in a given year depends on fishing quotas regulated by international agreements. In addition, the herring biomass depends on the victim-predator relationship with cod, and competition with sprat. A large increase in the amount of sprat since the early 90 s of the twentieth century in the northern areas of the Baltic Sea, the interspecies competition intensified, which led to the reduction of herring population in the northern Baltic. The average number of herring has stabilized since the late $90 \mathrm{~s}$, but remains low (EUP 2011). Herring feed mainly on zooplankton, above all on copepods, crustaceans and larvae of fish. Larger individuals (larger than $15 \mathrm{~cm}$ ) also feed on macroplankton and benthic organisms (Szypuła 1985; Last 1989; Arrhenius and Hansson 1994).

Adult herrings are a frequent component of the diet of predatory fish (e.g. cod), marine mammals (e.g. seals) and seabirds. Herring is also a paratenic host, on which nematodes parasitize - Anisakis Simplex (Grygiel 2014) as well littoral mysids from the species Neomysis integer, Praunus flexuosus, and P. inermis prey on herring eggs and yolk-sac larvae, if available (Torniainen and Lehtiniemi 2008).

\section{ANATOMY}

Herring has a strongly elongated body, rarely longer than $40 \mathrm{~cm}$, on average of 20-30 cm. There are local differences between the growth rate of small individuals from the northern Baltic and large individuals from the southern Baltic (FAO 2017). In the cross-section, the body is oval with a wedge (keel) on the abdomen, the keel hulls are not sharp (Terofal and Militz 1996). The remaining scales are circular, large, thin, which easily fall out. The head with the protruding mandible is not covered with a scales, and the gill cover is smooth. Herring has eyes with small eyelids. It does not have a side line. The dorsal fin is stiffened with 17-20 soft rays and begins halfway from the tip of the muzzle to the base of the caudal fin. The anal fin is stiffened with 16-18 soft rays. The caudal fin is deeply and visibly indented. The abdominal fins are located behind the base of the dorsal fin. Herring has a dark-gray or dark-green back, while the abdomen is silvery (Terofal and Militz 1996). On the gill arches, there are numerous, long filter appendices that facilitate feeding with plankton (Cech and Moyle 2004). The bladder is connected to the ear canal and the digestive tract, and apart from this, a separate cord goes out of the anus that extends from the anus to outside the body (Eschmeyer and Paxton 1998). This feature gives the herring sense of hearing, which is one of the most acute among fish (Cech and Moyle 2004). Herring releases 
air bubbles through the anal hole and this way makes noise. It is suggested that the release of bubbles may be related to the distraction of predators, such as plowing. It is possible that this may also be associated with communication between individuals in the shoal (Wahlberg and Westerberg 2003).

Herring is adapted to live in well-lit surface waters, where they form shoals and feed on plankton. Adaptations to life in such an environment are silvery scales (disperse light shining from above), small side flattened body (reduce the visibility of herring from below), which reduces the visibility of the fish.

\section{HERRING BREEDS}

Herring are divided into four subspecies:

1) Atlantic herring (Clupea harengus harengus), which lives in the North Atlantic and the Barents Sea, spawning takes place in late winter to early summer, reaches a large size of individuals and has at least 57 vertebrae;

2) Baltic herring (Clupea harengus membras), which lives in the Baltic Sea, spawning takes place in the winter to early spring, the number of vertebrae is below 55;

3) Pacific herring (Clupea harengus pallesii), found in the Pacific, Arctic and neighboring seas;

4) Chesha herring (Clupea harengus palasii suworowi) found in Chesha Bay.

These subspecies are distinguished mainly geographically, but they have differences in meristic features, especially in the number of vertebrae, body dimensions and in size after sexual maturity (Blaxter 1985).

Herring living in the Baltic Sea is significantly different from other herring populations (Popiel 1958) and hence is often treated as a separate subspecies. The typical Baltic line of herring is the line connecting Cape Rozewie with the southern shore of the Island of Öland. Baltic herring lives on the east of this arbitrarily adopted border. In popular vocabulary and popular-scientific publications, the names of herring related to the Baltic Sea habitats are also used, eg. Rügen herring, Hanö Bay herring, Gulf of Gdańsk herring, Gulf of Riga herring (Grygiel 2014). Baltic herring in different languages has names i.e. "strömming" in Sweden or "salaka" in Russia. Popiel (1958) noted that these names underlines the specific features of this species and these language differences today are still used to distinguish Baltic herring of these regions from "typical herring".

An expression of the adaptation of herring to changing environmental conditions is the division into separate populations, called by some ecological breeds, and by other herds. In the Baltic Sea, three main "local herds" are distinguished (Fig. 1), separated on the basis of place and time of spawning, feeding site, growth rate, fertility, migration routes, shape and structures of otoliths. Tomczak (2004) distinguished the following herds of Baltic herring:

1) West Baltic herring

a) Island of Rügen herring;

2) open sea herring

a) coastal herring of the Southern Baltic,

b) Southeast Baltic herring; 
3) bay herring
a) gulf of Riga herring,
b) gulf of Bothnia herring - northern,
c) gulf of Bothnia herring - southern,
d) gulf of Finland herring.

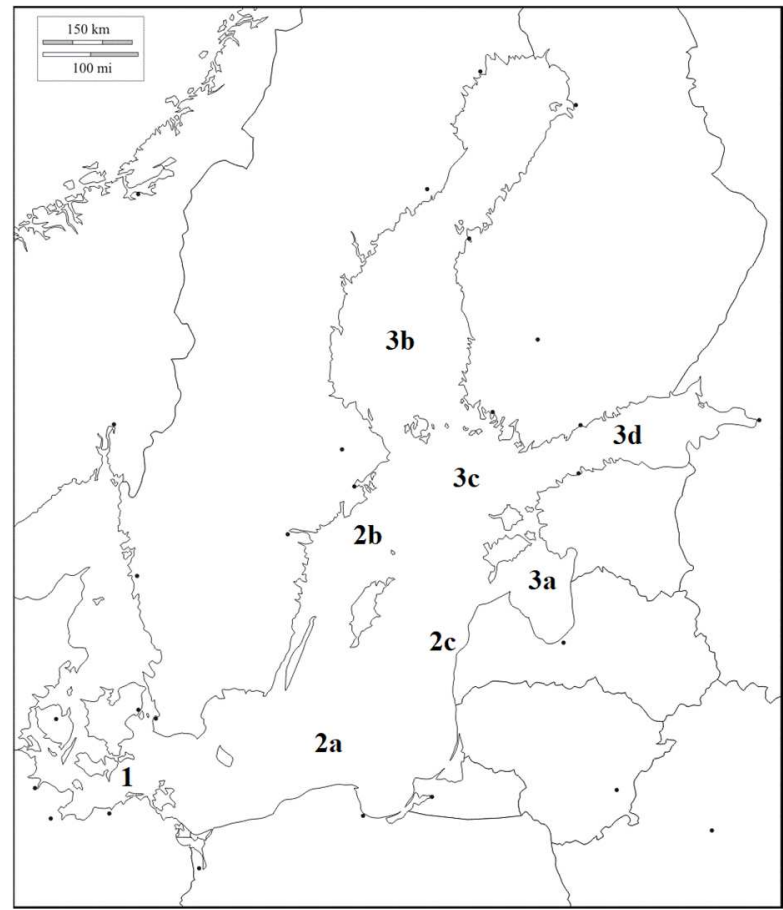

Fig. 1. Places of occurrence of particular herring herds. 1, 2, 3-the descriptions are given in the text Source: Tomczak (2004).

In the case of Atlantic herring living in the North Sea, a dozen or so herds are distinguished, each of which has its own spawning grounds and their own time for reproduction. Herring lays eggs near the coast, on the depth from a few to a dozen meters, sometimes up to 40 meters deep. Eggs stick to gravel, small stones or plants. Although herring does not belong to very fertile fish, and even large females rarely deposit more than one hundred thousand eggs, they appear on spawning grounds in such a number that the bottom is covered with multi-layered rugs of eggs (Załąchowski 1997). Fertility of Baltic herring is lower than Atlantic herring, mainly due to the worse condition of the Baltic herring (Bucholtz et al. 2013). Anner (1985 and 1987) observed filamentous green alga negatively affect fish eggs by released toxic substances. Similar to the North Sea area, herring in the western Baltic area constituted a single population. In this area, the number of vertebrae were stable over many decades. It is therefore assumed that herring in this area were fish managed as western Baltic spring spawner. However, in recent years, an increasing fraction of herring from the central Baltic has migrated further westwards into the western Baltic. Herring from the central Baltic have an even lower vertebral counts (Berg et al. 2017).

Baltic herring occurs in two main groups depending on the spawning period: spring herrings and autumn herrings. When the conditions are right, herring migrate to shallow waters near the spawning coast. Spring spawning takes place at depths of up to 10 meters, 
but spawning is also observed at greater depths. In the northern parts of the Baltic Sea, spring spawning occurs from April and May, until the end of July or the beginning of August. In the southern Baltic, herring spawn begins in February and March, and ends at the end of June (Fey et al. 2014). The autumn herring spawn is farther away from the shore at depths of about 20 meters (Fey et al. 2014). Herrings that breed in the spring usually have larger eggs and less fertility, while herring from autumn spawning is the opposite. This is explained by adaptation to thermal conditions. In the spring, when the water is colder, the development of the embryo lasts longer, so it needs more nutrients, but at the lower temperature, the activity of predators and consequently the losses they cause, is lower. In the autumn, the embryos hatched sooner, but the threat of predator activity increases (Załąchowski 1997). If eggs are spawned later in the season at higher temperatures, it is smaller, contain less yolk and hatched larvae are of worse condition (Clausen et al. 2007). With proceeding spawning season egg and larvae mortality increases (Rajasilta et al. 2006). Herring after spawning migrate from the coast to the open sea. It was established that the largest population of herring fish is found in waters furthest from the shore. Foraging areas are located in the Bornholm basin, the Sławno gutter, the Gdańsk bay and in areas west of Klaipeda (Popiel 1958).

\section{CATCHES OF HERRING}

Most of Baltic herring in 2017 was caught by Finland, as many as 157.5 thousand tones. The second position is Sweden with a mass of 94.3 thousand tonnes of herring caught. Poland caught 51.3 thousand tonnes of herring, which is about 2-3 times lower value than previous countries (Fig. 2). In 2011-2013, the Baltic herring catches in Poland were declining. However, since 2014, the volume of catches has been steadily growing every year (Fig. 3). Herring fishing takes place throughout the year with varying intensity. Also, the types of herring caught change depending on the season. These changes are marked with visible regularity. Depending on the age and breed of fish, we can distinguish three catch periods per year:

1. The winter/ spring period, which runs from December-January to March-April. It is characterized by the dominance of young herring. A large part are two-year herrings that reached maturity for their first spawning. Fishing during this period is not big. The fishery focuses on the southern part of the Gdańsk Bay and the area of the Bornholm basin closer to Poland.

2. Spring/ summer period: from March-April to May-June. During this period herring is dominating, which spawns in the autumn and concentrates in foraging grounds in the Bornholm basin, the Slupsk Furrow and the Klaipeda area. Older and larger herrings are the majority of fish caught during this time, but there are also two- and one-year-old fish. In total, spring herring is made up of young and immature individuals, as well as older and matured. The catches from this period are much larger than during the winter period.

3. Summer/ autumn period, from June-July to November-December. Spring spawning herrings from significantly older age groups, i.e. six, seven and eight years, dominate during this period. In addition, there is a small number of herrings from autumn spawning (Popiel 1958). 


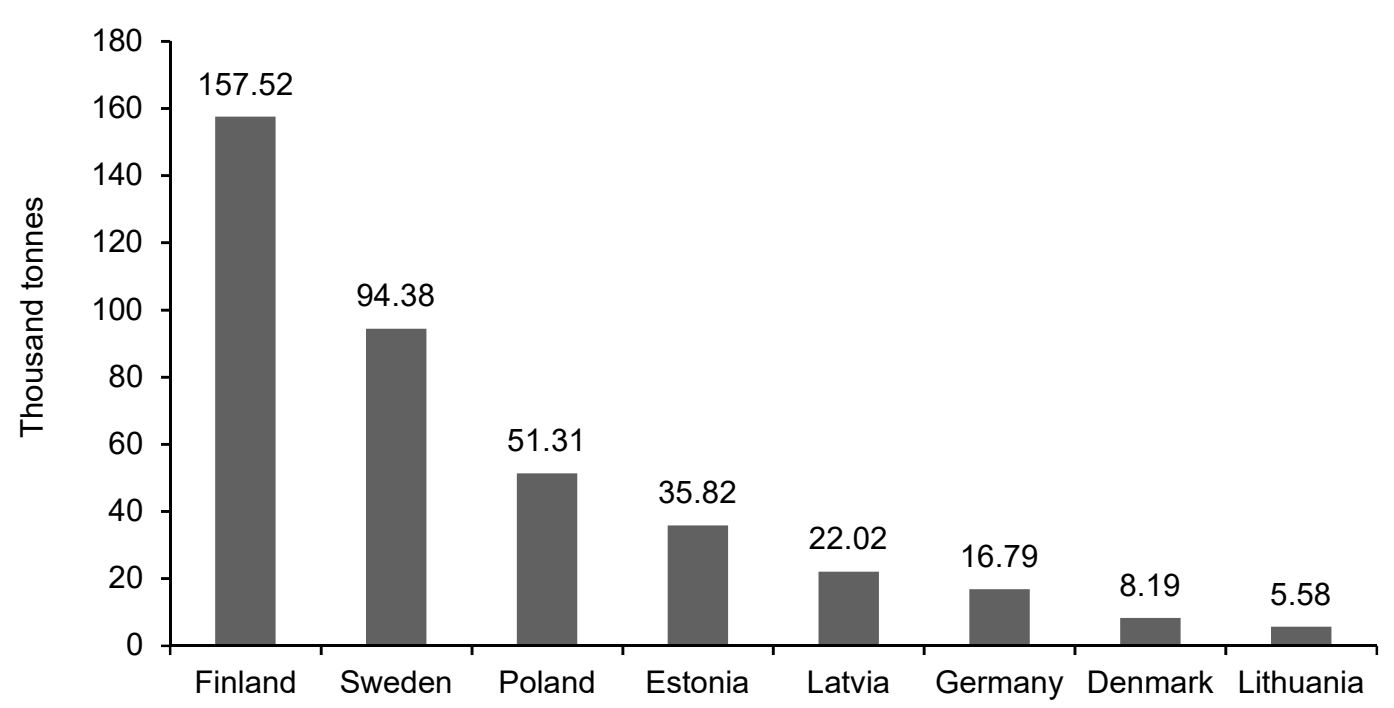

Fig. 2. Baltic herring catches by different countries in 2017

Source: Eksploatacja żywych zasobów Morza Bałtyckiego (2017).

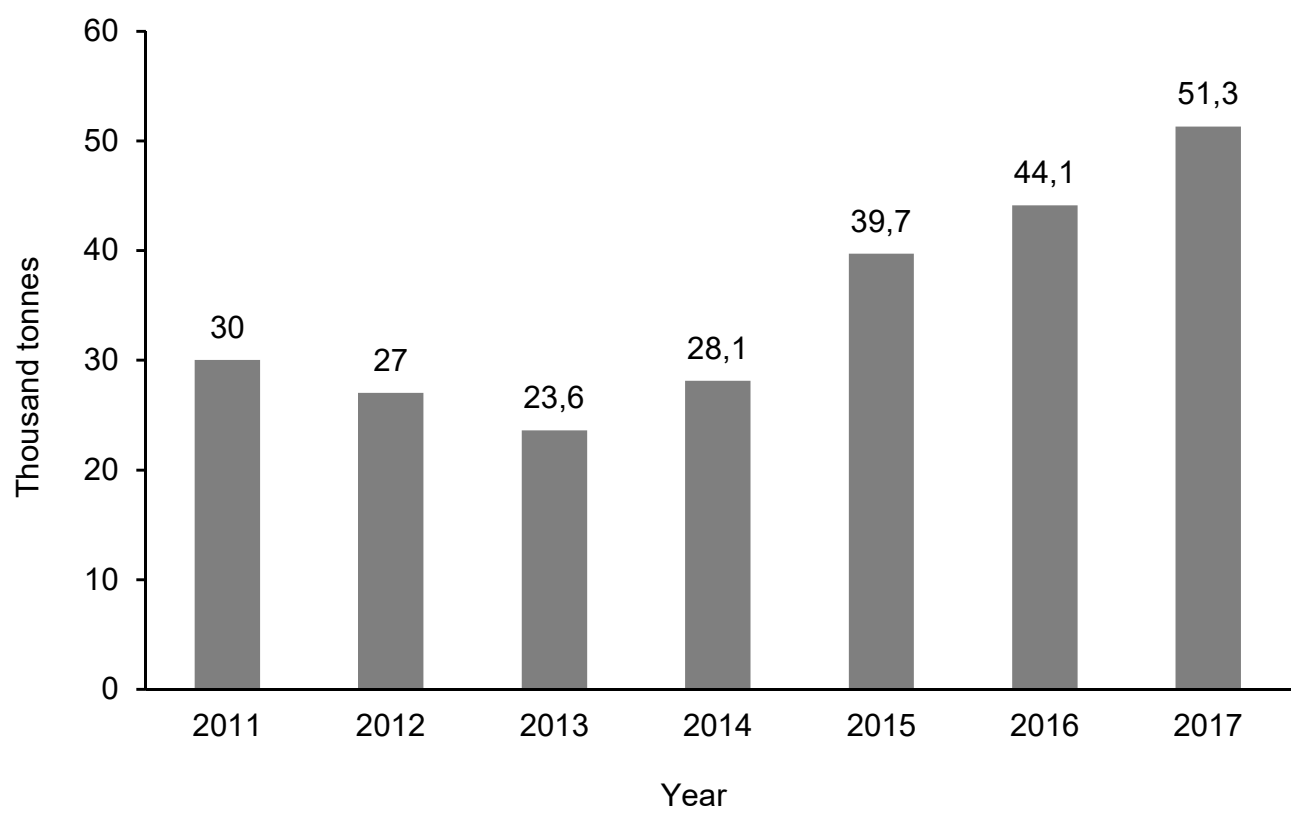

Fig. 3. The mass of Baltic herring catches in Poland in 2011-2017

Source: Kuzebski $(2015,2017)$.

\section{HERRING PROCESSING}

Due to the fat content, herring can be divided into the following groups:

- full-fat without sperm and roe, like matjas and ulik, fished before spawning;

- medium-fat and delicate, with sperm or roe, fished during spawning;

- common-lean herring, without roe and sperm, fished after spawning (Czerwińska 2005).

The season has a significant impact on the economic importance of herring. Maier (1908) set the seven-point scale of the stage of development of herring gonads, which is an indicator of optimal use of the material. During the year, the biggest changes are observed in the composition of the fat content in muscle tissue and the activity of hydrolytic enzymes in 
the tissue and gastrointestinal tract. These two parameters influence (i) the type of product to which the herring is best suited, (ii) production yield, (iii) processing parameters, (iv) taste and $(v)$ the conditions under which it can be stored. In the herring while feeding season, the content of fat in the body and the activity of enzymes in the gastrointestinal tract increases. That is why herrings from this season are best suited for traditional salting (in whole). In turn, in the case of herring caught during the spawning period, the fat content decreases with simultaneous high activity of muscle enzymes. It makes these herrings best suited for the production of marinated fillets. Fat herring tastes better than lean herring. What's more, from the economic point of view, fatty herring is more efficient in processing, due to the lower loss of water, because fat limits the contraction of the denatured protein. Lean herring is not always suitable for use because of too high hardness, and meat from it may not always reach its full potential during some types of heat treatments. On the other hand, low fat herring products can be stored longer. Therefore, the information about the herring fishing season and maturity, and consequently its fat content, is very important for the industry. With this information, the producer can take full advantage of the acquired material (Losier and Tchoukanova 2006).

Herring are mostly used for the production of canned food, marinades and smoked products (Table 2). In processing, more expensive products are made from Atlantic herring, this is due to the fact that these herrings are larger, have higher fat content and smaller amount of chemical impurities. Baltic herring by many researchers is treated as a worse material compared to Atlantic herring (Szymczak 2011), which is caused by higher protein losses and less activity of proteolytic enzymes during the processing of Baltic herring (Szymczak and Kołakowski 2012; Szymczak 2017). Therefore, the Baltic herring is mainly used for the production of marinades, herring corks and rollmops, canned herring, as well as herring preserves (Table 1). Larger and more fat Baltic Sea herring and especially Atlantic herring are intended for the production of marinated fillets in oil or Bismarck type fillets and are subjected to canning and smoking (Table 4). Salted herring, herring fillets and herring fillets in sauces and sour cream are the most popular chilled processed herring products among consumers (Fig. 4). In Germany the dominant type of canned herring is "herrings fillets in cans (oil/sauce)". In Poland are two main types of canned herring:

- canned herring fillets in oil/tomato/sauce - produced mainly from Atlanto-Scandinavian or North Sea herring;

- canned herring (carcasses) - produced from Baltic herring (different sizes).

Table 1. Processing of Baltic herring depending on its size

\begin{tabular}{|c|c|c|c|c|}
\hline $\begin{array}{l}\text { Type of } \\
\text { herring }\end{array}$ & Size class & $\begin{array}{l}\text { Mass of fish }[\mathrm{kg}] \\
\text { or length }[\mathrm{cm}]\end{array}$ & $\begin{array}{l}\text { Fish per kg } \\
\text { [items] }\end{array}$ & Products \\
\hline \multirow{4}{*}{$\begin{array}{l}\text { West Baltic } \\
\text { herring }\end{array}$} & 1 & $0.25 \mathrm{~kg}$ and more & 4 or less & $\begin{array}{l}\text { smoked, canned or salted } \\
\text { herrings, matiases }\end{array}$ \\
\hline & 2 & $0.125-0.25 \mathrm{~kg}$ & $5-8$ & $\begin{array}{l}\text { marinades, matiases, canned, } \\
\text { salted or smoked herrings }\end{array}$ \\
\hline & 3 & $0.085-0.125 \mathrm{~kg}$ & $9-11$ & marinades, canned \\
\hline & 4 & $0.05-0.085 \mathrm{~kg}$ & $12-20$ & - \\
\hline \multirow{3}{*}{$\begin{array}{l}\text { Eastern } \\
\text { Baltic and } \\
\text { southern } \\
\text { herring }\end{array}$} & $\mathrm{D}$ & $22-28 \mathrm{~cm}$ & \multirow{2}{*}{-} & smoked, marinades \\
\hline & $\mathrm{S}$ & $16-21 \mathrm{~cm}$ & & canned herring \\
\hline & undersized & $9-15 \mathrm{~cm}$ & & - \\
\hline
\end{tabular}

Source: Grygiel (2009); Karl and Münkner (2002). 


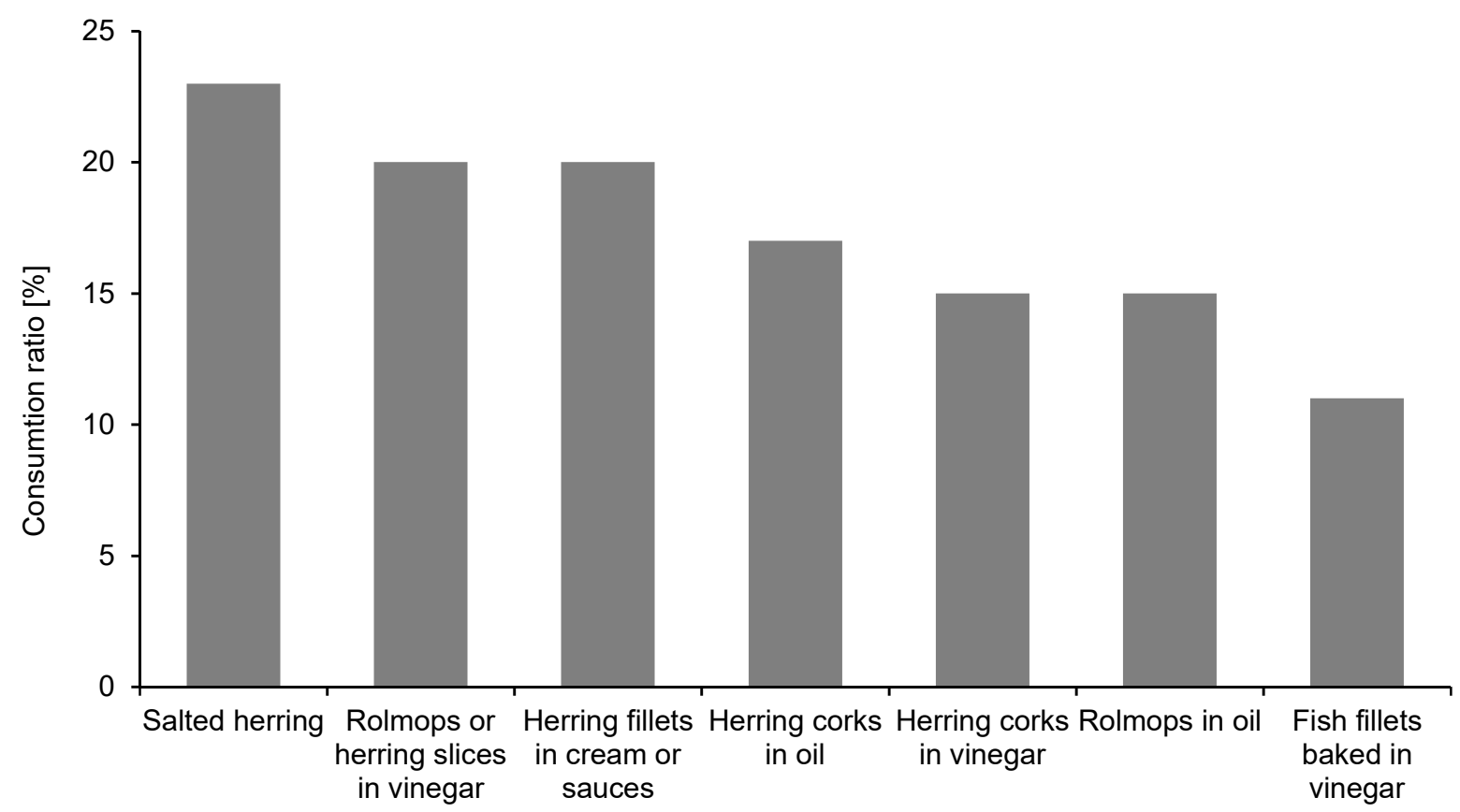

Fig. 4. Most popular herring products. The results do not add up to $100 \%$ (consumers could choose more than one product); \% means percentage of consumers in Poland who consumed a given product in 12 months before quantitative research made in 2011 Source: Kulikowski (2011).

Salted herrings are a traditional product, but for over a dozen years, this product gradually lose its importance in favour of herring pickles, what is due to the growing awareness of consumers of the impact of salt on health. For several years, it has been observed that fish marinades which were dominant on the market are also slowly losing their significance, and fish preserves in oil and tomato sauce become more popular (Table 2). Consumption of high-processed products such as salads and pastes is also increasing (Kulikowski 2017; Szostak and Drożdż 2018). Herring products, i.e. marinades, salted herrings, canned food and gourmet products which are characteristic herring preserves, constitute an important share in the structure of the fish industry in Poland (Fig. 4, Table 2).

Table 2. The structure of herring processing in Poland 2015-2016 in tonnes

\begin{tabular}{lccc}
\hline \multicolumn{1}{c}{ Assortment group/ years } & 2015 & 2016 & 2017 \\
\hline Smoked fish & 82.2 & 88.7 & 74.5 \\
\hline Marinated fish & 85.1 & 81.5 & 81.4 \\
\hline Canned fish & 56.3 & 62.1 & 63.8 \\
\hline Fresh fillets & 20.1 & 59.3 & 62.6 \\
\hline Frozen fillets & 25.9 & 31.6 & 32.4 \\
\hline Frozen fish & 25.4 & 23.3 & 22.7 \\
\hline Fish preserves & 20.2 & 21.1 & 21.3 \\
\hline Salted fish & 12.2 & 11.6 & 13.2 \\
\hline Frozen fish stuffing & 9.2 & 9.3 & 9.1 \\
\hline Delicatessen and other products & 51.0 & 59.4 & 62.0 \\
\hline Total production & 38.7 & 44.9 & 44.3 \\
\hline
\end{tabular}

Source: Kulikowski (2017); Szostak and Drożdż (2018). 


\section{NUTRITIONAL VALUE OF HERRING AND ITS PRODUCTS}

Its nutritional value depends significantly on the fishing season. The protein content in the herring is relatively constant throughout the year $(17 \%)$, while the fat and water content changes inversely proportionally (Table 3 ). In the case of Atlantic herring, the fat content ranges from 1 to $23 \%$, and Baltic herring from 1 to $10 \%$. This is related to the seasonality of feeding, the type of available food. It has been shown that the fat content in the herring is higher if the environment is rich in food and depends on the sexual maturity of the individuals (Losier and Tchoukanova 2006; FAO 2018).

The method of processing and the type of product obtained from fish material have a significant impact on the nutritional value. According to Usydus, Szlinder-Richert and Adamczyk (2009) the best products are those that are not subjected to excessive and too intensive heat treatment, i.e. sterilization. Therefore, the greater digestibility of protein and lipids have smoked (98\%), marinated (97.8\%) and salted (97,9\%) fish, in comparison to canned fish, for which the digestibility achives about $93 \%$. The digestibility of protein in canned fish is reduced by reactions between proteins and lipids, that take place at high temperatures (Usydus et al. 2009).

Herring belongs to fish that can be eaten raw. However, is recommended to consume herring only after deep freezing or processing, due to the risk of parasite contamination (EC 2005).

Table 3. Nutritional value of Baltic herring

\begin{tabular}{ccccc}
\hline kcal & Water [\%] & Proteins [\%] & Fats [\%] & Minerals [\%] \\
\hline $37.1-108.9$ & $72-81$ & $12-19.4$ & $1.0-10.0$ & $1.2-2.7$ \\
\hline
\end{tabular}

Source: Konerzewski et al. (1968).

Unsaturated fatty acids in herring are particularly valuable. Baltic herring has a high content of EPA and DHA acids $(940.9 \pm 306.6 \mathrm{mg} / 100 \mathrm{~g})$ and a favourable ratio of $\mathrm{n}-3$ to $\mathrm{n}-6$ fatty acids, which has a significant role in the prevention of cardiovascular diseases. Fillets from Baltic herring are a good source of many essential elements. The content of elements such as iron, zinc, manganese, calcium and potassium are high comparing their recommended daily intake values. If the skin and bones from the carcass are removed, the levels of calcium and zinc decrease significantly, but they will still remain relatively high (Tahvonen et al. 2000). Herring is also a good source of vitamins $A(6 \mu \mathrm{m} / 100 \mathrm{~g}), D(11.5 \mu \mathrm{m} / 100 \mathrm{~g}), B 12$ $(14 \mu \mathrm{m} / 100 \mathrm{~g})$ and $\mathrm{E}(2.0 \mu \mathrm{m} / 100 \mathrm{~g})$ (Grygiel 2014).

Herring meat is sensitive to autooxidation process catalysed with $\mathrm{Cu}^{2+}$ copper ions. In the order in which fish are ranks due to the sensitivity to autooxidation, herring are in the first place. This order according to decreasing vulnerability is as follows: fatty fish meat (herring, mackerel) > medium fatty (crimson, flatfish) > scallop meat > lean fish meat (cod, haddock) > crustacean meat (lobster, prawn, crab). Changes in fish fat can lead to a deterioration in the colour of the fish during storage. Loss of the desired colour results, among others from the transformation of carotenoid dyes under the influence of oxidation products of unsaturated fatty acids (Sikorski 1992). 
In order to avoid excessive intake of dioxins and dioxin-like polychlorinated biphenyls, the amount of consumed of Baltic herring should not be higher than $100 \mathrm{~g}$ each day of the week. For comparison, the consumption of salmon should not be higher than $100 \mathrm{~g}$ portions twice a week (Usydus et al. 2011).

\section{HERRING BY-PRODUCTS}

Fish industry is characterized with the biggest losses and the higher production of food byproducts occurring during processing. These losses range from 50 to even $75 \%$ of the mass of raw material (Szymczak et al. 2017). Already at the stage of fishing, about six percent of herring is classified as not suitable for consumption in a conventional form, i.e. canned food, fresh fish, etc. (Ankenman-Granata 2012). The reason is the massive catch, during which herring is damaged under the outflow of large pressure forces (Szymczak and Szymczak 2016).

Currently, the following by-products are obtained during herring processing: fish meal, fish oil, pearl essence (Smárason et al. 2017). In addition, more and more often also protein and enzymes are recovered (Smárason et al. 2017). The best source of hydrolytic enzymes are guts, which constitute about $15 \%$ of herring's weight, which is comparable to other marine fish $($ Table 4,5$)$. For the production of such materials as fish meal and fish oil, heads, fins, skins, backs and guts are used. There are used also fresh, but mechanically damaged herring, which are not microbial contaminated. Fish from the herring family are one of the best materials for obtaining oils because the fat in their body is not only distributed in the liver as in other fish, but in the whole body (Aidos 2002).

Despite the many advantages of Baltic herring, Pihlajamäki et al. (2016) reported that wild caught herring greater than $17 \mathrm{~cm}$ may exceed the maximum allowable dioxide level. For this reason, the European Union has introduced restrictions on the use of this raw material on the food and feed market (EUP 2011).

Table 4. The average mass of individual body parts in percentage by weight of Baltic herring

\begin{tabular}{cccc}
\hline Muscles & Guts & Gonads & Head \\
\hline 61.7 & 15.0 & 4.3 & 21.0 \\
\hline
\end{tabular}

Source: Konerzewski et al. (1968).

Table 5. Example of mass from each by-products in various marine fish [\%]

\begin{tabular}{lccccc}
\hline \multicolumn{1}{c}{ Fish } & Head & Guts & Skin & Spine and bones & Total share \\
\hline Herring & 16 & $13-20$ & 8 & 10 & $47-54$ \\
\hline Mackerel & 17 & $13-18$ & 8 & 10 & $48-53$ \\
\hline Cod & $23-26$ & $15-20$ & 6 & 17 & $61-69$ \\
\hline
\end{tabular}

Source: Szymczak et al. 2017.

\section{SUMMARY}

Herring is a traditional fish for Polish culture, but still underestimated by many. This fish occupies a similar position in traditional cuisines also in other countries, especially in Scandinavia, Germany, Denmark, Estonia and Latvia. Herring meat composition indicates 
that they are a valuable element of the diet and the promotion of this fish could improve the overall consumption of marine fish. This is especially important because the availability and price of herring is attractive to the consumer. For the industry, however, searching for new techniques and methods that will increase production efficiency or enable wider use of emerging by-products is an important direction of research and development.

\section{REFERENCES}

Aidos I. 2002. Production of high-quality fish oil from herring byproducts. PhD thesis. Wageningen University, Nederland (unpublished).

Aneer G. 1985. Some speculations about the Baltic Herring (Clupea harengus membras) in connection with the eutrophication of the Baltic Sea. Canad. J. Fish. Aquatic Sci. 42(Suppl. 1), 83-90.

Aneer G. 1987. High natural mortality of Baltic herring (Clupea harengus) eggs caused by algal exudates? Marine Biol. 94, 163-169.

Ankenman-Granata L., Flick G.J.Jr., Martin R.E. 2012. The seafood industry: species, products, processing, and safety, 2nd ed. Virginia, USA, The Wiley-Blackwell Publisher, 432.

Arrhenius F., Hansson S. 1994. In situ food consumption by young-of-the-year Baltic Sea herring Clupea harengus. A test of predictions from a bioenergetics model. Marine Ecol. Progr., Ser. 110, 145-149.

Berg F., Slotte A., Johannessen A., Kvamme C., Clausen L.W., Nash R.D.M. 2017. Comparative biology and population mixing among local. Coastal and offshore Atlantic herring (Clupea Harengus) in the North Sea, Skagerrak, Kattegat And Western Baltic. PLoS One 12(10), 1-19.

Blaxter J.H.S. 1985. The herring: A successful species. Canad. J. Fish. Aquatic. Sci. 42(1), 21-30.

Bucholtz H.R., Tomkiewicz J., Nyengaard R.J., Andersen B.J. 2013. Oogenesis, fecundity and condition of Baltic herring (Clupea harengus L.). A stereological study. Fisher. Res. 145(1), 100-113.

Cech J.J., Moyle P.B. 2004. Fishes an introduction to ichthyology, 5th ed. Massachusetts, United States, Prentice-Hall, 726.

Clausen L.A.W, Ulrich-Rescan C., Van Deurs M., Skagen D. 2007. Improved advice for the mixed herring stocks in the Skagerrak and Kattegat. Report No.Fish/2004/03. Copenhagen, Denmark EU Rolling Programme, 75.

Czerwińska D. 2005. Apetyt na śledzia [Taste for herring]. Prz. Gastronom. 4, 8-9. [in Polish]

EC. 2005. Regulation no 853/2004 of the European parliament and of the council of 29 April 2004 laying down specific hygiene rules for food of animal origin, https://eurlex.europa.eu/LexUriServ/ /LexUriServ.do?uri=OJ:L:2004:139:0055:0205:EN:PDF, access: 18.01.2019.

Eksploatacja żywych zasobów Morza Bałtyckiego [Exploatation of living resources of the Baltic Sea]. 2017. Mag. Przem. Ryb. 5(119), 16. [in Polish]

Eschmeyer W.N., Paxton J.R. 1998. Encyclopedia of fishes, 2nd ed. San Diego, United States, Academic Press, 240.

EUP. 2011. Commission regulation (EU) No. 1259/2011 of 2 December 2011 amending Regulation (EC) No. 1881/2006 as regards maximum levels for dioxins, dioxin-like PCBs and non-dioxin-like PCBs in foodstuffs, https://eur-lex.europa.eu/LexUriServ/LexUriServ.do?uri=OJ:L:2011:320:0018:0023: EN:PDF, access: 18.01.2019.

FAO. 2018. Corporate document respository. Herring, http://www.fao.org/wairdocs/tan/x5933e/ /x5933e01.htm, access: 15.01.2019.

FAO. 2018. Species fact sheets - Clupea harengus, http://www.fao.org/fishery/species/2886/en, access: 15.01.2019.

Fey D., Hiller A., Margonski P., Moll D., Nilsson H., Pongolini L., Stybel N., Szymanek L. 2014. Herring impact report. Herring spawning areas - present and future challenges. Report No. 4-2014. Warnemünde, Germany, The Coastal Union Germany. 
Grygiel W. 2014. Bałtyckie ryby śledziowate - ich nazwy i znaczenie pozarybackie [Baltic herring fish - their names and meanings beyond fishing]. Wiad. Ryb. 9-10(201), 13-18. [in Polish]

GUS. 2016. Gospodarka morska w Polsce 2015 roku, https://stat.gov.pl/obszary-tematyczne/transport-i-lacznosc/transport/gospodarka-morska-w-polsce-w-2015-roku,7,13.html, access: 10.01.2019. [in Polish]

Hernandez-Padilla J.C., Ruiz-Barreiro T.M., Salcedo-Bojorquez S., Espinosa-Romero M.J., Zetina-Rejon M.J., Arreguin-Sanchez F. 2017. The ecological role of Opisthonema libertate and Cetengraulis mysticetus on ecosystem order in The Southeastern Gulf of California, Mexico. Turkish J. Fisher. Aquatic Sci. 17, 713-724.

Karl H., Münkner W. 2002. Quality and processing possibilities of Western Baltic Sea spring spawning herring. J. Aquatic Food Prod. Technol. 11(3/4), 31-43.

Karnicki Z. 2017. Na początek roku [At the beginning of the year]. Wiad. Ryb. 1-2, 1-3. [in Polish]

Konerzewski J., Ligocki H., Ogulewicz J. 1968. Towaroznawstwo ryb. Warszawa, Wydaw. Przem. Lekkiego Spożyw. [in Polish]

Kulikowski T. 2011. Preferencje konsumentów marynat rybnych [Consumer preferences of fish pickles]. Mag. Przem. Ryb. 4(82), 35. [in Polish]

Kulikowski T. 2017. Wyniki przetwórstwa rybnego w Polsce [The results of fish processing in Poland]. Mag. Przem. Ryb. 5(119), 16. [in Polish]

Kuzebski E. 2015. Dobre wyniki rybołówstwa bałtyckiego w 2014 r. [Good results of the Baltic fisheries in 2014]. Wiad. Ryb. 3-4(204), 4-7 [in Polish]

Kuzebski E. 2017. Dobre wyniki rybołówstwa bałtyckiego w 2016 r. [Good results of the Baltic fisheries in 2016]. Wiad. Ryb. 3-4(216), 12-15. [in Polish]

Last J.M. 1988. The food of herring, Clupea Harengus, in the North Sea, 1983-1986. J. Fish Biol. 4(34), 489-501.

Losier M., Tchoukanova N. 2006. Herring quality: from catch to multiple markets review of the literature. Shippagan, Canada, Coastal Zones Research Institute, 111.

Maier H.N. 1908. Beiträge zur Altersbestimmung der Fische. I. Allgemeines. Die Altersbestimmung nach Otolithen bei Scholle und Kabeljau. Die Arbeiten der Deutschen Wissenschaftlichen Kommission für Meeresforschung. B5, 8-15

MRiRW. 2009. Kompleksowa ocena segmentu pelagicznego polskiego rybołówstwa bałtyckiego celem wskazania możliwości podniesienia jego efektywności poprzez wdrażanie programu operacyjnego "Zrównoważony rozwój sektora rybołówstwa i nadbrzeżnych obszarów rybackich 2007-2013" w szczególności Osi 1: Środek 1.3, Osi 2: Środek 2.5 i Osi 3: Środki 3.3 i 3.4, http://mgm.gov.pl/ /minrol/content/download/22771/119736/version/1/file/kompleks.\%20ocena.pdf, access: 15.01.2019. [in Polish]

Od kilku lat rośnie konsumpcja ryb [Fish consumption has been growing for several years]. 2015. Mięs. Technol. 1, 100. [in Polish]

Pihlajamäki M., Sarkk S., Karjalainen T.P. 2016. Food or feed? The contribution of Baltic herring fisheries to food security and safety, in: Food futures: ethics, science and culture, ed. A.S. Olsson, S.M. Araújo, M.FF. Vieira. Porto, Portugal, Wageningen Academic Publishers, 625.

Popiel J. 1958. Differentiation of the biological groups of Herring in the southern Baltic. ICES Marine Sci. Symp. 143(2), 114-121.

Rajasilta M., Eklund J., Laine P., Jönsson N., Lorenz T. 2006. Intensive monitoring of spawning populations of the Baltic herring (Clupea harengus membras L.). Report No. 96-068. Turku, Finland, SEILI Archipelago Research Institute Publications.

Sikorski Z.E. 1992. Morskie surowce żywnościowe. Warszawa, WNT, 245. [in Polish]

Smárason B.Ö., Ögmundarson Ó., Árnason J., Björnsdóttir R., Davíðsdóttir B. 2017. Life cycle assessment of Icelandic Arctic char fed three different feed types. Turkish J. Fisher. Aquatic Sci. 17, 79-90. 
Szostak S., Drożdż J. 2018. Przetwórstwo i popyt na ryby i owoce morza. Przetwórstwo [Processing and demand for fish and seafood. Processing]. Rynek Ryb. Stan i Persp. Analizy Rynk. 28(1), 23-25. [in Polish]

Szymczak M. 2011. Comparison of physicochemical and sensory changes in fresh and frozen herring (Clupea harrengus L.) during marinating. J. Sci. Food Agric. 91(1), 68-74.

Szymczak M. 2017. Effect of technological factors on the activity and losses of cathepsins B, D and L during marinating of Atlantic and Baltic herrings. J. Sci. Food Agric. 97(5), 1488-1496.

Szymczak M., Dominiczak A., Szymczak B. 2017. Odzyskiwanie białka z rybnych surowców ubocznych [Recovering protein from fish by-products]. Przem. Spoż. 71, 24-28. [in Polish]

Szymczak M., Kołakowski E. 2012. Losses of nitrogen fractions from herring to brine during marinating. Food Chem. 132(1), 237-243.

Szymczak M., Szymczak B. 2016. Cenne właściwości ryb problem w przetwórstwie [Valuable fish properties problem in processing]. Przem. Spoż. 70(9), 39-42. [in Polish]

Szypuła J. 1985. Comparative studies on herring and sprat feeding in the southern Baltic within 1978-1982. Acta Ichth. Piscat. 15(2), 75-93.

Tahvonen R., Aro T., Nurmi J., Kallio H. 2000. Mineral content in Baltic herring and Baltic herring products. J. Food Comp. Anal. 13, 893-903.

Terofal F., Militz C. 1996. Leksykon przyrodniczy - ryby morskie. Warszawa, Świat Książki, 288. [in Polish]

Tkaczewska J., Migdał W., Kulawik P. 2014. Preferencje konsumentów w zakresie spożycia ryb [Consumer preferences for fish consumption]. Kom. Ryb. 1(138), 10-14. [in Polish]

Tomczak M.T. 2004. Historia i sposoby gospodarowania zasobami śledzi centralnego Bałtyku [History and manners of the resource management the central Baltic Sea herring]. Mag. Przem. Ryb. 5(41), 14-17. [in Polish]

Torniainen J., Lehtiniemi M. 2008. Potential predation pressure of littoral mysids on herring (Clupea harengus membras L.) eggs and yolk-sac larvae. J. Exp. Mar. Biol. Ecol. 367(2), 247-252.

Usydus Z., Szlinder-Richert J., Adamczyk M. 2009. Protein quality and amino acid profiles of fish products available in Poland. Food Chem. 112, 139-145.

Usydus Z., Szlinder-Richert J., Adamczyk M., Szatkowska U. 2011. Marine and farmed fish in the Polish market: Comparison of the nutritional value. Food Chem. 126, 78-84.

Von Dorrien C., Hammer C., Zimmermann C., Stepputtis D., Stuermer I. W., Kotterba P., Patrick P. 2013. A review on herring, Clupea harengus (Actinopterygii: Clupeiformes: Clupeidae). Recruitment and early life stage ecology in the Western Baltic Sea. Acta Ichth. Piscat. 43, 169-182.

Wahlberg M., Westerberg H. 2003. Sounds produced by herring (Clupea harengus) bubble release. Aquatic Living Res. 16(3), 271-275.

Więcaszek B., Krzykawski S., Antoszek A., Keszka S. 1999. Podstawy systematyki krągłoustych i ryb. Przewodnik do wykładów i ćwiczeń dla studentów studiów zaocznych Wydziału Rybactwa Morskiego i Technologii Żywności. Szczecin, AR, 196. [in Polish]

Załąchowski W. 1997. Ryby. Warszawa, Wydaw. Nauk. PWN, 528. [in Polish]

\section{ICHTIOLOGIA I EKONOMICZNE ZNACZENIE ŚLEDZIA BAŁTYCKIEGO W POLSKIM PRZEMYŚLE RYBNYM}

Streszczenie. W przypadku polskiego rybołówstwa śledź jest powszechnym surowcem pozyskiwanym z Morza Bałtyckiego. Pomimo homogeniczności tego gatunku śledź jest podzielony na wiele różnych typów ze względu na położenie geograficzne. Różnice w cechach anatomicznych między typami śledzia wskazują na wiele cech adaptacyjnych do środowiska, w których żyje ten gatunek. Podział geograficzny wpływa na okres rozrodczy, ilość jaj złożonych, wielkość jaj i okres tarła. Atrybuty te są związane z warunkami środowiskowymi 
danego sezonu. Śledź należy do tłustych ryb, co ma wpływ na właściwości mięsa, metody przetwarzania i rodzaje produktów, które można z niego uzyskać. Okres tarła decyduje o wydajności masy podczas przetwarzania śledzia i jakości sensorycznej gotowych produktów. Mięso śledzia jest dobrym źródłem niezbędnych nienasyconych kwasów tłuszczowych, niezbędnych aminokwasów, minerałów i witamin. Skład mięsa śledzia wskazuje, że jest ono korzystnym składnikiem codziennej diety. Ponadto cena rynkowa ryb należących do tego gatunku jest niska, w odniesieniu do cen innych ryb. Dodatkową korzyścią jest to, że również uboczne produkty ze śledzi znajdują zastosowanie technologiczne, co zmniejsza straty w przetwórstwie ryb.

Słowa kluczowe: śledź bałtycki, ichtiologia, przemysł rybny, surowce uboczne, wartość odżywcza. 